\title{
Antitumor potential of natural products from marine ascidians of the Gibraltar Strait:
}

\author{
A survey

\section{Potencialidad antitumoral de productos naturales marinos de ascidias del Estrecho de Gibraltar: Una panorámica}

\author{
Eva Zubía \\ María J. Ortega \\ Javier Salvá* \\ Departamento de Química Orgánica \\ Facultad de Ciencias del Mar y Ambientales \\ Universidad de Cádiz \\ 11510 Puerto Real, Cádiz, España \\ * E-mail: javier.salva@uca.es \\ Recibido en enero de 2003; aceptado en marzo de 2003
}

\begin{abstract}
The chemical study of a selection of marine ascidians from the Gibraltar Strait has led to the characterization of a collection of natural products of diverse biosynthetic origin. The structures were elucidated by spectroscopic methods and, in certain instances, the absolute stereochemistry was determined using chiral auxiliaries following the Mosher method. In particular, the new compounds isolated from the ascidians Phallusia fumigata (Grübe, 1864), Botryllus leachi (Savigny, 1816), Stolonica socialis (Hartmayer, 1903), and Pseudodistoma obscurum (Pères, 1959) are presented and key aspects of the structural elucidation are discussed. In order to anticipate a possible antitumor application, the cytotoxicity of the new compounds was evaluated against cell lines P-388 (suspension culture of a lymphoid neoplasm from a DBA/2 mouse), A-549 (monolayer culture of a human lung carcinoma), HT-29 (monolayer culture of a human colon carcinoma), and MEL-28 (monolayer culture of a human melanoma).
\end{abstract}

Key words: natural products, ascidians, structure elucidation, cytotoxicity.

\section{Resumen}

El estudio químico de una serie de ascidias seleccionadas procedentes del Estrecho de Gibraltar ha llevado a la caracterización de una colección de productos naturales de muy diverso origen biosintético. Las estructuras se establecieron mediante métodos espectroscópicos y, en algunos casos, la estereoquímica absoluta se determinó usando auxiliares quirales siguiendo el método de Mosher. En concreto, se presentan los nuevos compuestos aislados a partir de las ascidias Phallusia fumigata (Grübe, 1864), Botryllus leachi (Savigny, 1816), Stolonica socialis (Hartmayer, 1903) y Pseudodistoma obscurum (Pères, 1959) y se discuten aspectos clave acerca de la elucidación estructural. Para poder anticipar una posible aplicación antitumoral, se ha realizado una evaluación de citotoxicidad de los nuevos compuestos frente a las líneas celulares P-388 (cultivo en suspensión de un neoplasma linfoide de ratón DBA/2), A-549 (cultivo en monocapa de un carcinoma de pulmón humano), HT-29 (cultivo en monocapa de un carcinoma de colon humano) y MEL-28 (cultivo en monocapa de un melanoma humano).

Palabras clave: productos naturales, ascidias, elucidación estructural, citotoxicidad.

\section{Introduction}

Marine organisms have proved to be a rich source of bioactive natural products. During the past 20 years, marine natural product chemists in collaboration with pharmacologists, both academic and industrial, have described a large number of novel compounds with useful biomedical properties. The number and quality of leads generated more than justify research on marine pharmacology (Faulkner, 2000).

\section{Introducción}

Se ha demostrado que los organismos marinos son una rica fuente de productos naturales bioactivos. Durante los últimos 20 años los químicos que trabajan en productos naturales marinos en colaboración con farmacólogos, tanto de universidades como de empresas privadas, han descrito un elevado número de nuevos compuestos con propiedades biomédicas de interés. El número y calidad de los compuestos cabezas de serie 
In the area of cancer research, pharmacologically active marine compounds have traditionally played a prominent role. Thus, after the discovery of Taxol ${ }^{\mathrm{R}}$ and its stabilizing microtubules mode of action, three marine natural compounds have exhibited a similar biological behaviour: discodermolide, eleutherobin and sarcodictyin A. In general, the biological material that has received more attention in this field of research are marine invertebrates of the groups of sponges, molluscs, bryozoans, corals and ascidians. In particular, ascidians are well known producers of nitrogenous metabolites and among the marine-derived compounds that have entered phase I and II trials as antitumor agents, two of them, ecteinascidin 743 and aplidine, are derived from ascidians. Ecteinascidin 743 or ET-743 (Yondelis ${ }^{\mathrm{TM}}$ ) is an alkaloid obtained from the ascidian Ecteinascidia turbinata (Rinehart et al., 1990; Wright et al., 1990), which was licensed to PharmaMar S.A. and which currently undergoes the final steps in the clinical trials to become an anticancer drug exhibiting a unique mode of action (D'Incalci et al., 2002). Aplidine is a cyclic depsipeptide of the well known didemnin family that was isolated from the ascidian Aplidium albicans (Rinehart et al., 1989) and that is currently undergoing phase I clinical trials under the auspices of PharmaMar S.A.

The projects carried out by our research group in this area have been aimed to the discovery of new cytotoxic metabolites from marine invertebrates, mainly of the southern coast of Spain. In this context, in the present paper we survey the progress achieved in the study of the antitumor agents from a selection of ascidians collected in the Gibraltar Strait. The biological material of this group of invertebrates, after extraction and preliminary chemical analysis, was fractioned following a bioassay guided isolation approach and, finally, the compounds responsible for the activity were identified using spectroscopic methods.

\section{Materials and methods}

The organic extracts from each marine ascidian were fractioned using column chromatography. The fractions obtained were analyzed using thin layer chromatography and ${ }^{1} \mathrm{H}$ nuclear magnetic resonance (NMR) spectroscopy. Final separations using both normal and reversed phase high performance liquid chromatography (HPLC) enabled us to obtain pure compounds.

Identification and structural elucidation were performed using organic spectroscopy techniques such us ${ }^{1} \mathrm{H}$ and ${ }^{13} \mathrm{C}$ NMR and mass spectrometry, as well as infrared (IR) and ultraviolet (UV) spectroscopy. In particular, ${ }^{1} \mathrm{H}$ and ${ }^{13} \mathrm{C}$ NMR spectra were made at 399.952 and $100.577 \mathrm{MHz}$, respectively, using $\mathrm{CDCl}_{3}, \mathrm{CD}_{3} \mathrm{OD}$ or pyridine- $\mathrm{d}_{5}$ as solvents. In HPLC separations, LiChrosorb Si 60 was used in normal phase mode and LiChrosorb RP-18 in reversed phase mode, using in both cases a differential refractometer and a UV detector. All solvents used were spectral grade or distilled from glass prior to use. generados justifica con creces la investigación en farmacología marina (Faulkner, 2000).

En el campo de investigación del cáncer, los compuestos de origen marino con actividad farmacológica han desempeñado tradicionalmente un papel preponderante. Así, tras el descubrimiento del Taxol ${ }^{\mathrm{R}}$ y su mecanismo de acción de estabilización sobre los microtúbulos, otros tres productos naturales marinos han exhibido un comportamiento biológico similar: discodermolido, eleutherobina y sarcodictina A. En general, el material biológico que ha recibido más atención en este campo de investigación son los invertebrados marinos de los grupos de las esponjas, moluscos, briozoos, corales y ascidias. En concreto, las ascidias son productores bien conocidos de metabolitos nitrogenados y entre los compuestos marinos que han entrado en las fases I y II como agentes antitumorales, dos de ellos, la ecteinascidina 743 y la aplidina, proceden de ascidias. La ecteinascidina 743 o ET-743 (Yondelis ${ }^{\mathrm{TM}}$ ) es un alcaloide obtenido de la ascidia Ecteinascidia turbinata (Rinehart et al., 1990; Wright et al., 1990) que se licenció a PharmaMar S.A., y que actualmente cursa los pasos finales en las pruebas clínicas como fármaco anticancerígeno que exhibe un modo de acción único (D’Incalci et al., 2002). La aplidina es un depsipéptido cíclico de la bien conocida familia de las didemninas que se obtuvo de la ascidia Aplidium albicans (Rinehart et al., 1989) y actualmente se encuentra en la fase clínica I bajo los auspicios de PharmaMar S.A.

Los proyectos realizados por nuestro grupo de investigación en este campo han estado encaminados al descubrimiento de nuevos metabolitos citotóxicos procedentes de invertebrados marinos, principalmente de la costa sur de España. En este sentido, en el presente trabajo revisamos los progresos logrados en el estudio de agentes antitumorales a partir de una colección de ascidias recolectadas en el Estrecho de Gibraltar. El material biológico de este grupo de invertebrados, tras su extracción y un análisis químico preliminar, se fraccionó siguiendo una estrategia basada en la bioactividad $y$, finalmente, los compuestos responsables de la actividad se identificaron usando métodos espectroscópicos.

\section{Materiales y métodos}

Los extractos orgánicos de cada una de las ascidias marinas se fraccionaron usando cromatografía en columna. Las fracciones obtenidas se analizaron usando cromatografía en capa fina y resonancia magnética nuclear protónica ( ${ }^{1} \mathrm{H}$ NMR). Las separaciones ulteriores usando cromatografía líquida de alta eficacia (HPLC), tanto en fase normal como en fase reversa, nos permitieron obtener los compuestos en estado puro.

La identificación y elucidación estructural se realizaron usando técnicas espectroscópicas orgánicas tales como resonancia magnética nuclear protónica y de carbono $13\left({ }^{1} \mathrm{H}\right.$ y ${ }^{13} \mathrm{C}$ NMR) y espectrometría de masas, así como espectroscopías infrarroja (IR) y ultravioleta (UV). En particular, los espectros de ${ }^{1} \mathrm{H}$ y ${ }^{13} \mathrm{C}$ NMR se realizaron a 399.952 y $100.577 \mathrm{MHz}$, respectivamente, usando $\mathrm{CDCl}_{3}, \mathrm{CD}_{3} \mathrm{OD}$ o piridina- $\mathrm{d}_{5}$ como 
The antitumor screening assays were performed employing the following cell lines: P-388 (suspension culture of a lymphoid neoplasm from a DBA/2 mouse), A-549 (monolayer culture of a human lung carcinoma), HT-29 (monolayer culture of a human colon carcinoma), and MEL-28 (monolayer culture of a human melanoma). Cells were maintained in logarithmic phase of growth in Eagle's Minimun Essential Medium.

Two methods for inhibition of cell growth have been employed: the first, by counting total cell numbers using an adapted form of the Bergeron method (Bergeron et al., 1984) and 24 well microtiter plates; the second, by counting viable cells using 96 well microtiter plates and the colorimetric method (Mosmann, 1983; Faircloth et al., 1988). The samples assayed have been plated over cell lines in logarithmic growth phase. The length of incubation has depended on each cell line growth rate.

The results of these assays have been used to generate dose-response curves from which the $\mathrm{IC}_{50}$ value has been calculated for each case (sample concentration which produces $50 \%$ of cell growth inhibition).

\section{Results}

The ascidian Phallusia fumigata (Grübe, 1864) from Tarifa Island, near the Gibraltar Strait, contained a series of new glucosphingolipids, the phallusides 1-4 [1-4] (fig. 1). The phallusides represent the first report of glucosphingolipids isolated from ascidians and three of them [1-3] contain the uncommon sphingoid base 2-amino-9-methyl-D-erythro-(4E, 8E, 10E)-octadeca-4,8,10-triene-1,3-diol (Durán et al., 1998).

The red ascidian Botryllus leachi (Savigny, 1816), from Tarifa Island, contained two novel pyrazine alkaloids, botryllazine A [5] and botryllazine B [6], and the new imidazole alkaloid 2-( $p$-hydroxybenzoyl)-4-( $p$-hydroxyphenyl)imidazole [7] (fig. 2). Botryllazine A [5] represents the first example of a marine alkaloid containing a pyrazine nucleus derived from three tyrosine precursors. Two of the new alkaloids exhibited a mild cytotoxicity against the tumor cell lines assayed (Durán et al., 1999).

The colonial ascidian Stolonica socialis (Hartmayer, 1903), from Tarifa Island, contained a new class of strongly cytotoxic acetogenins named stolonoxides A-D [8-11] (fig. 3). The structures of the stolonoxides present a 1,2-dioxane ring disolventes. En las separaciones mediante HPLC se usó LiChrosorb Si 60 en fase normal y LiChrosorb RP-18 en fase reversa, usando en ambos casos detectores de refractometría diferencial y ultravioleta. Todos los disolventes utilizados fueron de grado espectroscópico o destilados en vidrio antes de su uso.

En los ensayos antitumorales se utilizaron las siguientes líneas de células tumorales: P-388 (cultivo en suspensión de un neoplasma linfoide de ratón DBA/2), A-549 (cultivo en monocapa de un carcinoma de pulmón humano), HT-29 (cultivo en monocapa de un carcinoma de colon humano) y MEL-28 (cultivo en monocapa de un melanoma humano). Las células se mantuvieron en fase logarítmica de crecimiento en el Medio Mínimo Esencial de Eagle.

Para la inhibición del crecimiento celular se utilizaron dos métodos: el primero, mediante el recuento del número total de células utilizando una adaptación del método de Bergeron (Bergeron et al., 1984) usando placas de 24 pocillos; y el segundo, contando células viables usando placas de 96 pocillos mediante el método colorimétrico (Mosmann, 1983; Faircloth et al., 1988). Las muestras ensayadas se depositaron sobre placas conteniendo las líneas celulares en fase logarítmica de crecimiento. El periodo de incubación en cada caso ha dependido de la velocidad de crecimiento de la línea celular considerada.

Los resultados de estos ensayos se usaron para generar curvas de dosis-respuesta de las que se calculó el valor de $\mathrm{IC}_{50}$ en cada caso (concentración de muestra que causa un $50 \%$ de inhibición del crecimiento celular).

\section{Resultados}

La ascidia Phallusia fumigata (Grübe, 1864) de la Isla de Tarifa, junto al Estrecho de Gibraltar, contenía una serie de nuevos glucoesfingolípidos, las phallusidas 1-4 [1-4] (fig. 1). Las phallusidas representan el primer ejemplo de glucoesfingolípidos aislados de ascidias y tres de ellas [1-3] contenían la inusual base esfingoide 2-amino-9-metil-D-eritro-(4E, 8E, 10E)-octadeca-4,8,10-trieno-1,3-diol (Durán et al., 1998).

La ascidia roja Botryllus leachi (Savigny, 1816), de la Isla de Tarifa, contenía dos alcaloides pirazínicos novedosos, botryllazina A [5] y botryllazina B [6], y el nuevo alcaloide imidazólico 2-( $p$-hidroxibenzoil)-4-( $p$-hidroxifenil)imidazol [7] (fig. 2). La botryllazina A [5] constituye el primer ejemplo
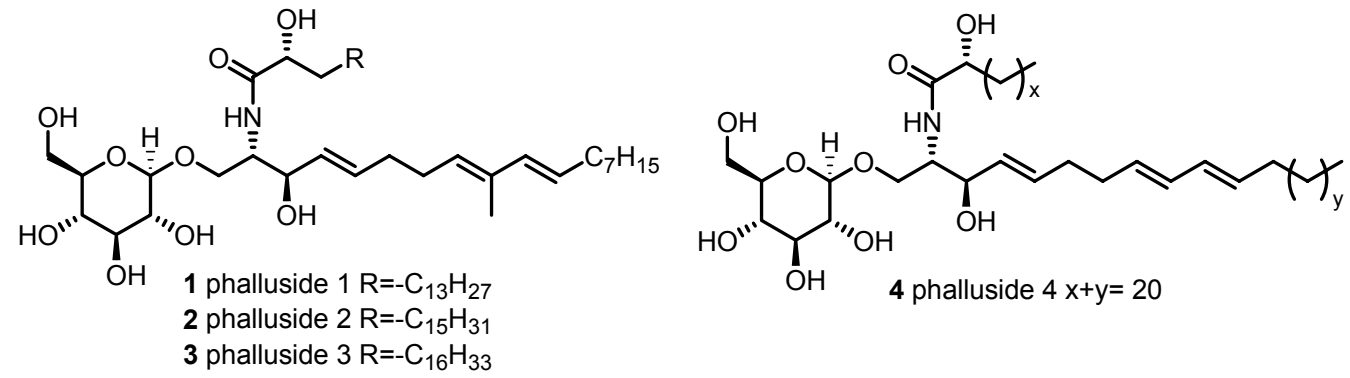

Figure 1 / Figura 1 

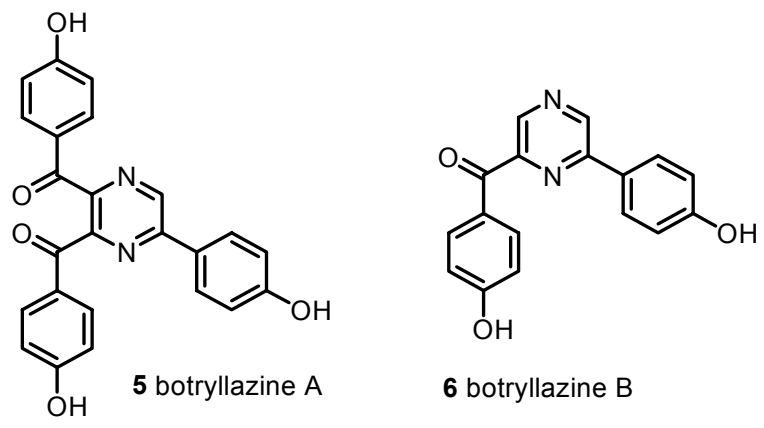

6 botryllazine B

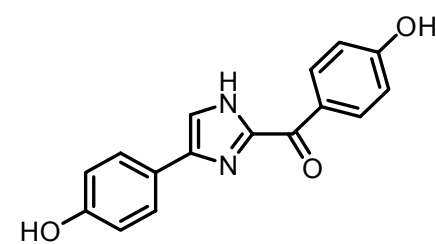

7 2-(p-hydroxybenzoyl)-

4-( $p$-hydroxyphenyl)imidazole

Figure 2 / Figura 2

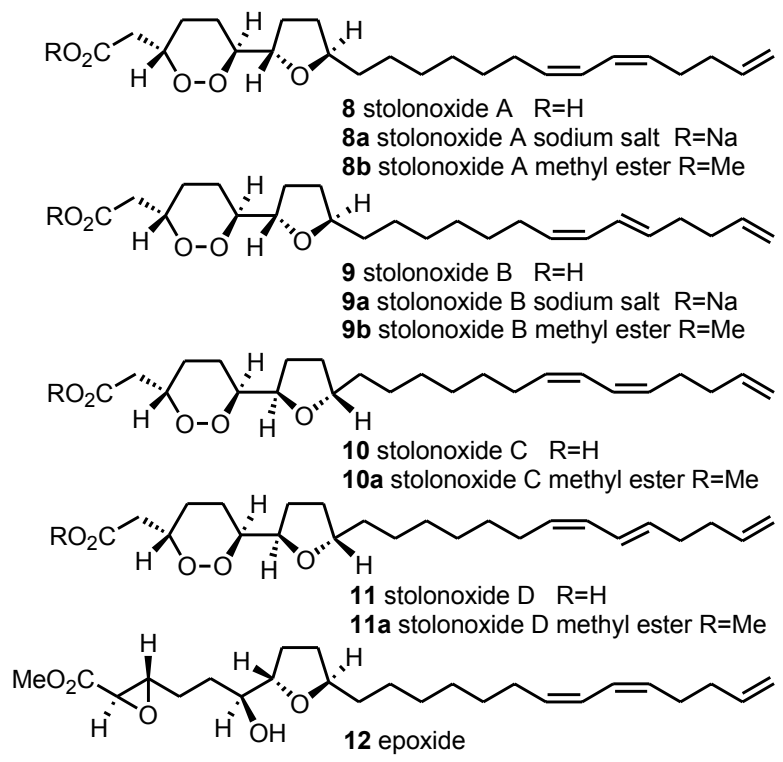

Figure 3 / Figura 3

linked to a tetrahydrofuran nucleus and were established by spectroscopic study of both the natural mixtures, whose components differ in the geometry of a double bond, and of the corresponding methyl esters. Derivatization by treatment with base afforded epoxide $\mathbf{1 2}$ and application of the Mosher method allowed unambiguous elucidation of the absolute stereochemistry $3 S, 6 S, 7 S, 10 R$ for stolonoxide A [8]. The stolonoxides exhibited a powerful cytotoxicity in antitumor testing (Durán et al., 2000).

The ascidian Pseudodistoma obscurum (Pères, 1959), from Tarifa Island, has led to the characterization of six new unsaturated 2-amino-3-ol compounds: the obscura-minols A-F [13-18] (fig. 4). Their structures were established by spectroscopic analysis, their relative configurations by NOEDS study of oxazolidinone derivatives, and their absolute configurations by application of the Mosher method to the $N$-acetyl derivatives of the natural components. Although the obscuraminols A-F [13-18] were active enough to employ cytotoxicity guided fractionation, no significant activities were encountered in the tests performed (Garrido et al., 2001). de un alcaloide marino que contiene un núcleo de pirazina derivado de tres precursores tirosínicos. Dos de los nuevos alcaloides exhibieron una citotoxicidad moderada frente al panel de células tumorales ensayado (Durán et al., 1999).

La ascidia colonial Stolonica socialis (Hartmayer, 1903), de la Isla de Tarifa, contenía una nueva clase de acetogeninas fuertemente citotóxicas denominadas stolonóxidos A-D [8-11] (fig. 3). La estructura de los stolonóxidos presenta un anillo de 1,2-dioxano unido a uno de tetrahidrofurano y se estableció por el estudio espectroscópico tanto de las mezclas naturales, cuyos componentes difieren en la geometría de un doble enlace, como de los correspondientes ésteres metílicos. La derivatización por tratamiento con base dio lugar a un epóxido 12 (fig. 3) y la aplicación del método de Mosher permitió la elucidación inequívoca de la estereoquímica absoluta $3 S, 6 S, 7 S, 10 R$ para el stolonóxido A [8]. Los stolonoxidos exhibieron una fuerte citotoxicidad en los ensayos antitumorales (Durán et al., 2000).

La ascidia Pseudodistoma obscurum (Pères, 1959), de la Isla de Tarifa, ha llevado a la caracterización de seis nuevos compuestos 2-amino-3-ol insaturados: los obscuraminoles A-F [13-18] (fig. 4). Sus estructuras se establecieron por análisis espectroscópico, sus configuraciones relativas por estudios NOEDS sobre derivados oxazolidinónicos y sus configuraciones absolutas por aplicación del método de Mosher a los $\mathrm{N}$-acetil derivados de los componentes naturales. Aunque los obscuraminoles A-F [13-18] fueron lo suficientemente activos para seguir el fraccionamiento guiado por bioensayos, no se encontraron valores de actividad significativos en los ensayos realizados (Garrido et al., 2001).

\section{Discusión}

En el desarrollo de nuestro proyecto de investigación dirigido a la búsqueda de compuestos antitumorales en ascidias marinas del Estrecho de Gibraltar, recolectamos ejemplares de Phallusia fumigata. La fracción de polaridad media de un extracto en acetona-metanol dio lugar, después de separación usando tanto columna de silica gel como HPLC en fase reversa, a los nuevos glucoesfingolípidos phallusidas 1-4 [1-4] (fig. 1). En general, los glicoesfingolípidos son un grupo amplio de biomoléculas anfipáticas que contienen dos 


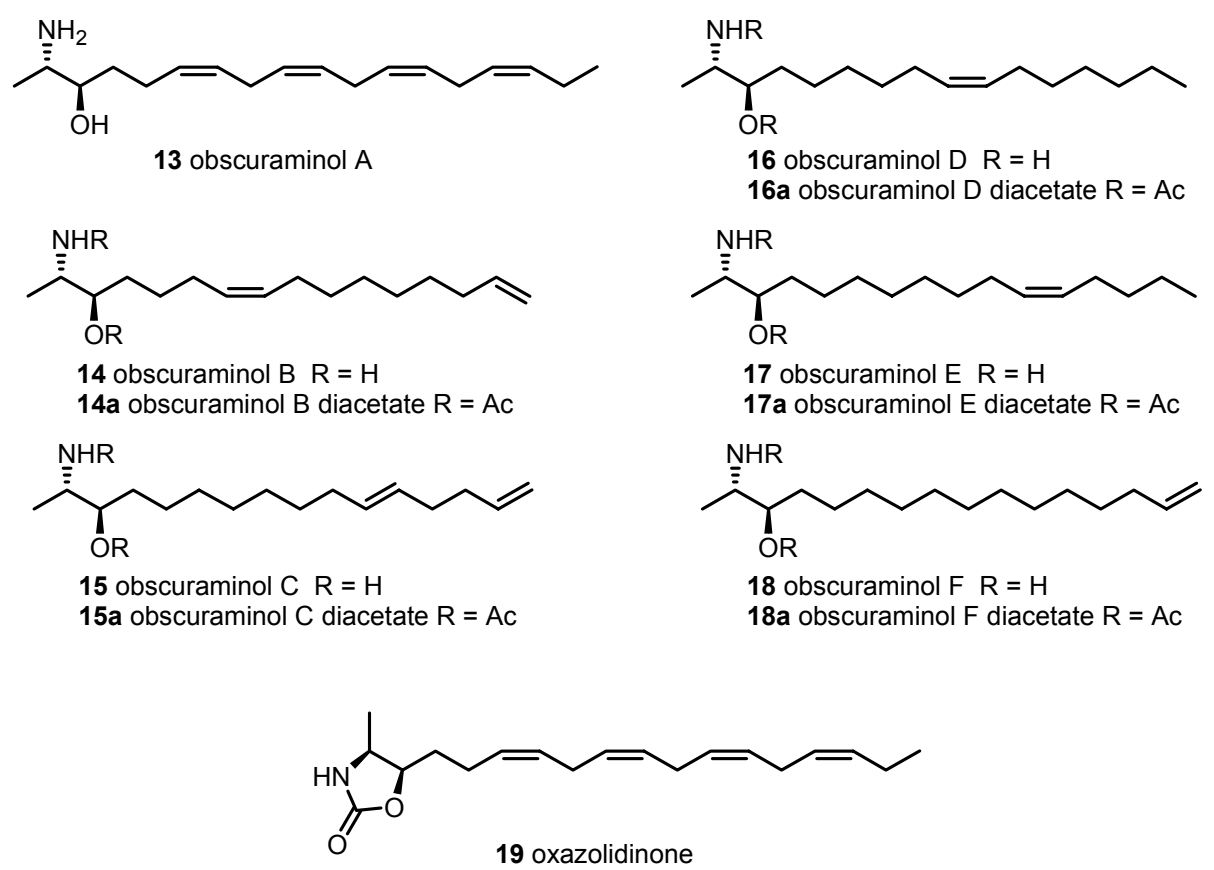

Figure 4 / Figura 4

\section{Discussion}

In our ongoing project directed toward the search for antitumor compounds from marine ascidians of the Gibraltar Strait, we collected specimens of Phallusia fumigata. The medium polar fraction of an acetone-methanol extract afforded, after separation both on silica gel column and reversed phase HPLC, the new glucosphingolipids phallusides 1-4 [1-4] (fig. 1). In general, glycosphingolipids are a large group of amphipathic biomolecules containing two basic structural units: a sugar and a hydrophobic ceramide that involves a sphingoid base amide linked to a fatty acid derived acyl chain.

The IR and NMR spectroscopic data of the phallusides were quite similar. The IR absorptions at 3400, 1650 and $1540 \mathrm{~cm}^{-1}$ indicated the presence of hydroxyl and amide groups. The ${ }^{13} \mathrm{C}$ NMR signal at $\delta 105.7$ (d) together with the ${ }^{1} \mathrm{H}$ NMR doublet around $\delta 4.9$ were assigned to the anomeric methine of a $\beta$-glucopyranoside moiety, which, in addition, gave rise to the carbon signals at $\delta 78.6(\mathrm{~d}), 78.5$ (d), 75.2 (d), $71.6(\mathrm{~d})$ and $62.7(\mathrm{t})$, and to a series of proton signals in the ${ }^{1} \mathrm{H}$ NMR spectrum at $\delta 4.5-3.8$. The $N$-alkylamide functionality was ascertained by the ${ }^{13} \mathrm{C}$ NMR signals at $\delta 175.7$ (s) and 54.6 (d). These common spectroscopic features together with the presence of a series of aliphatic and olefinic signals suggested that the phallusides were a series of glucosphingolipids with slight structural differences. Nevertheless the structure of each component could be elucidated by an extensive study of their ${ }^{1} \mathrm{H},{ }^{13} \mathrm{C}$ NMR and FAB mass spectra, as well as by the study of the derivatives produced by methanolysis of the natural compounds. unidades estructurales básicas: un azúcar y una ceramida hidrófoba que incluye una base esfingoide unida a través de una amida a una cadena acílica derivada de ácido graso.

Los datos espectroscópicos de IR y NMR de las phallusidas eran muy similares entre sí. Las absorciones IR a 3400, 1650 y $1540 \mathrm{~cm}^{-1}$ indicaban la presencia de grupos hidroxilo y amida. La señal de ${ }^{13} \mathrm{C}$ NMR a $\delta 105.7$ (d) junto con el doblete en el ${ }^{1} \mathrm{H}$ NMR aproximadamente a $\delta 4.9$ se asignó al metino anomérico de un $\beta$-glucopiranósido que, además, daba lugar a las señales de carbono a $\delta 78.6$ (d), 78.5 (d), 75.2 (d), 71.6 (d) y 62.7 (t), y a una serie de señales de protón en el espectro de ${ }^{1} \mathrm{H}$ NMR a $\delta$ 4.5-3.8. La función $N$-alquilamida se confirmó por las señales de ${ }^{13} \mathrm{C}$ NMR a $\delta 175.7$ (s) y 54.6 (d). Estas características espectroscópicas comunes, junto con la presencia de una serie de señales alifáticas y olefínicas sugerían que las phallusidas eran una serie de glucoesfingolípidos con ligeras diferencias estructurales. Sin embargo, la estructura de cada componente pudo ser elucidada por un estudio exhaustivo de sus espectros de ${ }^{1} \mathrm{H},{ }^{13} \mathrm{C}$ NMR y de masas $\mathrm{FAB}$, así como por el estudio de los derivados obtenidos por metanolísis de los compuestos naturales.

Las phallusidas encontradas en $P$. fumigata constituyen el primer caso de glucoesfingolípidos obtenidos de ascidias. Se había reportado que los ophidiacerebrósidos estructuralmente relacionados (Jin et al., 1994) habían mostrado una fuerte citotoxicidad in vitro frente a células leucémicas L-1210 y que las agelasphinas (Natori et al., 1994) habían mostrado actividad antitumoral in vivo frente a melanoma de murina B16. Sin embargo, aunque el extracto en acetona-metanol de $P$. fumigata había exhibido citotoxicidad frente a la línea celular A-549 $\left(\mathrm{IC}_{50}=5 \mu \mathrm{g} / \mathrm{mL}\right)$, las phallusidas probadas $[\mathbf{1 , 2}]$ 
Table 1. Cytotoxicity assay results against four tumor cell lines quantified using $I C_{50}$ values $(\mu \mathrm{g} / \mathrm{mL})$.

Tabla 1. Resultados de los ensayos de citotoxicidad frente a cuatro líneas de celulas tumorales cuantificada usando valores $I C_{50}(\mu \mathrm{g} / \mathrm{mL})$

\begin{tabular}{lllllll}
\hline Compound & Source & P-388 & A-549 & HT-29 & MEL-28 & Reference \\
\hline Phalluside 1 [1] & Phallusia fumigata & $>10$ & $>10$ & $>10$ & $>10$ & Durán et al., 1998 \\
Phalluside 2 [2] & Phallusia fumigata & $>10$ & $>10$ & $>10$ & $>10$ & Durán et al., 1998 \\
Phalluside 3 [3] & Phallusia fumigata & $>10$ & $>10$ & $>10$ & $>10$ & Durán et al., 1998 \\
Phalluside 4 [4] & Phallusia fumigata & $>10$ & $>10$ & $>10$ & $>10$ & Durán et al., 1998 \\
Botryllazine A [5] & Botryllus leachi & $>10$ & $>10$ & $>10$ & $>10$ & Durán et al., 1999 \\
Botryllazine B [6] & Botryllus leachi & 10 & 5 & 10 & 5 & Durán et al., 1999 \\
Imidazole 7 & Botryllus leachi & 5 & 5 & 5 & 5 & Durán et al., 1999 \\
Stolonoxides 8/9 & Stolonica socialis & 0.01 & 0.10 & 0.10 & 0.10 & Durán et al., 2000 \\
Stolonoxides 8a/9a & Stolonica socialis & 0.05 & 0.10 & 0.10 & 0.10 & Durán et al., 2000 \\
Stolonoxides 10/11 & Stolonica socialis & 0.01 & 0.01 & 0.05 & 0.10 & Durán et al., 2000 \\
Obscuraminol A [15] & Pseudodistoma obscurum & 2.5 & 2.5 & 5 & 2.5 & Garrido et al., 2001 \\
Acetates 14a/18a & Synthesis & 5 & 5 & 10 & 10 & Garrido et al., 2001 \\
\hline
\end{tabular}

The phallusides encountered in P. fumigata are the first account of glycosphingolipids obtained from ascidians. Structurally related ophidiacerebrosides (Jin et al., 1994) have been reported to show strong cytotoxicity against L-1210 leukaemia cells in vitro and the agelasphins (Natori et al., 1994) have shown in vivo antitumor activity against B16 murine melanoma. However, although the acetone-methanol extract of $P$. fumigata had exhibited cytotoxicity against A-549 cell line $\left(\mathrm{IC}_{50}=5 \mu \mathrm{g} / \mathrm{mL}\right)$, the phallusides assayed $[1,2]$ were inactive in the cytotoxicity tests performed against the tumor cell lines mentioned above (table 1).

The red ascidian Botryllus leachi from Tarifa Island provided an example of the well known issue that ascidians are a rich source of nitrogen containing metabolites (Faulkner, 2002). Frozen specimens of $B$. leachi were extracted with an acetone-methanol mixture. The n-butanol soluble material was chromatographed on silica gel and final purification using HPLC allowed the isolation of two novel pyrazine alkaloids, botryllazine A [5] and botryllazine B [6], together with the new imidazole derivative 7 (fig 2). The structures of compounds 5-7 were elucidated by interpretation of spectral data, being especially important the analyses of the ${ }^{1} \mathrm{H}-{ }^{13} \mathrm{C}$ couplings to define the nature of the pyrazine nucleus and, therefore, to discard the pyridazine and pyrimidine alternatives in the structures of the botryllazines A and B $[\mathbf{5}, \mathbf{6}]$.

The biogenetic pathway through which the botryllazines might derive from tyrosine precursors in B. leachi deserves some remarks. The double condensation of two amino acid units with amide formation leads to a diketopiperazine 3,6disubstituted by the $\alpha$-chains of the corresponding precursors. On the other hand, the biosynthesis through the connection of each amine group with $\mathrm{C}-2$ of the other precursor, likely via benzylic oxidation an imine formation, leads to a 2,5-disubstituted piperazine ring. Representative examples resultaron ser inactivas en los ensayos de citotoxicidad realizados frente al panel de líneas de células tumorales anteriormente mencionadas (tabla 1).

La ascidia roja Botryllus leachi de la Isla de Tarifa constituyó un ejemplo acerca del hecho bien conocido de que las ascidias son una rica fuente de metabolitos nitrogenados (Faulkner, 2002). Los ejemplares congelados de B. leachi se extrajeron con una mezcla de acetona-metanol. El material soluble en $n$-butanol se cromatografió sobre gel de sílice y una purificación final usando HPLC permitió el aislamiento de dos novedosos alcaloides, botryllazina A [5] y botryllazina B [6], junto con el nuevo derivado imidazólico 7 (fig. 2). Las estructuras de los compuestos 5-7 se elucidaron por interpretación de los datos espectroscópicos, siendo especialmente importantes los análisis de los acoplamientos ${ }^{1} \mathrm{H}-{ }^{13} \mathrm{C}$ para definir la naturaleza del núcleo pirazínico $\mathrm{y}$, de esta forma, descartar las alternativas de piridazina y pirimidina en las estructuras de las botrillazinas A and B [5, 6].

La ruta biogenética a través de la cual podrían derivar las botryllazinas a partir de precursores tirosínicos en $B$. leachi merece un comentario. La doble condensación de dos unidades de aminoácido con formación de amida lleva a dicetopiperazinas 3,6-disustituídas por las cadenas en $\alpha$ de los correspondientes precursores. Por otro lado, la biosíntesis a través de la conexión de cada grupo amino con el C-2 del otro precursor, presumiblemente vía oxidación benzílica y formación de imina, conduce a anillos de piperazina 2,5-disustituidas. En el esquema 1 se presentan algunos ejemplos representativos (Fahy et al., 1991; Fu et al., 1998) de metabolitos marinos derivados a través de estas dos rutas. Ninguna de las dos rutas mencionadas proporciona una explicación satisfactoria a la novedosa estructura de la botryllazina B [6]. Sin embargo, parece biosinteticamente factible la condensación de tirosina con tiramina para dar una amida seguida de ciclización vía 


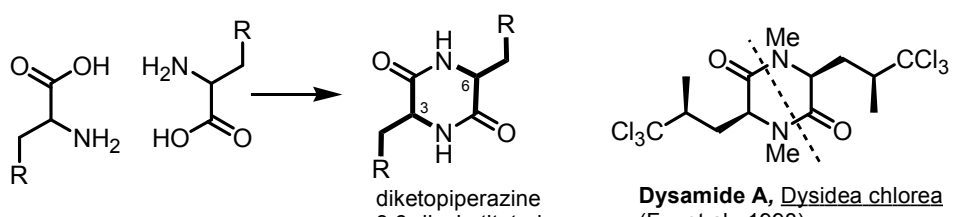
3,6-disubstituted (Fu et al., 1998)

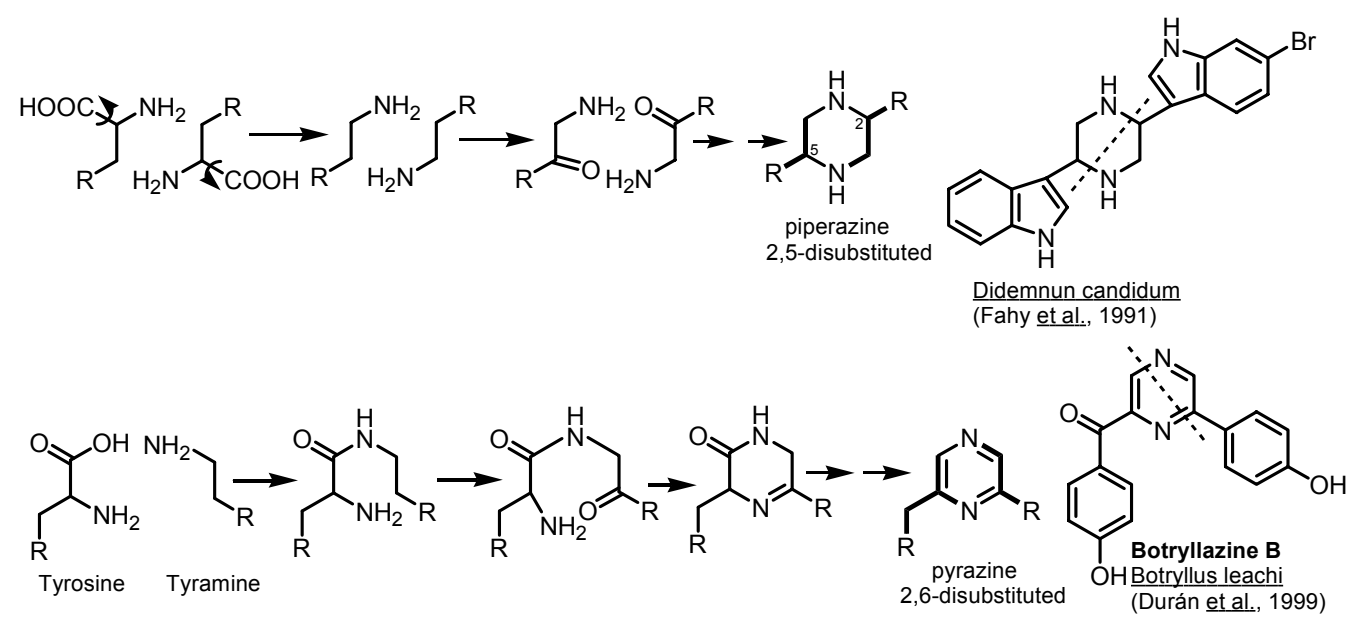

Scheme 1 / Esquema 1

(Fahy et al., 1991; Fu et al., 1998) of marine metabolites derived through these two biosynthetic routes are given in scheme 1. Neither of these routes provides a satisfactory explanation to the novel structure of botryllazine B [6]. However, it might be biosynthetically plausible to propose a tyrosine condensation with tyramine to afford an amide followed by cyclization via imine as in the second route mentioned above. The structure of botryllazine $A$ [5] is unprecedented since three tyrosine derived units are involved in the formation of the pyrazine nucleus. However, the way in which these units condense with each other is not apparent (Durán et al., 1999).

Although the crude extract of $B$. leachi had shown significant cytotoxicity against the tumor cell lines P-388, A-549, HT-29 and MEL-28, botryllazine A [5] was inactive with $\mathrm{IC}_{50}$ values over $10 \mu \mathrm{g} / \mathrm{mL}$ in all cases. Botryllazine B [6] exhibited a mild cytotoxicity against A-549 and MEL-28 cell lines $\left(\mathrm{IC}_{50}=5 \mu \mathrm{g} / \mathrm{mL}\right)$. Imidazole compound 7 exhibited a moderate cytotoxicity $\left(\mathrm{IC}_{50}=5 \mu \mathrm{g} / \mathrm{mL}\right)$ against the four tumor cell lines tested; however, the close relation of its structure with those of the bis(indolyl)imidazoles topsentines (Bartik et al., 1987), which are well known antiinflamatory agents of marine origin, led us to propose the new alkaloids from B. leachi as promising candidates for antiinflamatory testing (table 1).

Unlike the ascidians mentioned above, the chemical study of Stolonica socialis from Tarifa Island resulted in the isolation of a series of non-nitrogenous metabolites, a less frequent result in the chemistry of ascidians. Frozen specimens of $S$. socialis were extracted with an acetone-methanol mixture (1:1). After evaporation of the solvent, the aqueous residue was extracted with diethyl ether to yield a cytotoxic extract imina como en la segunda de las rutas mencionadas. La estructura de la botryllazina A [5] no tiene precedentes puesto que hay involucradas tres unidades de tirosina en la formación del núcleo de pirazina. Sin embargo, la forma en las que estas unidades condensan unas con otras no es evidente (Durán et al., 1999).

Aunque el extracto inicial de $B$. leachi había mostrado una citotoxicidad significativa frente a las líneas celulares tumorales P-388, A-549, HT-29 y MEL-28, la botryllazina A [5] resultó ser inactiva con valores de $\mathrm{IC}_{50}$ por encima de $10 \mu \mathrm{g} / \mathrm{mL}$ en todos los casos. La botryllazina B [6] exhibió una citotoxicidad suave frente a las líneas celulares A-549 y MEL-28 $\left(\mathrm{IC}_{50}=5 \mu \mathrm{g} / \mathrm{mL}\right)$. El compuesto imidazólico 7 exhibió una citotoxicidad moderada $\left(\mathrm{IC}_{50}=5 \mu \mathrm{g} / \mathrm{mL}\right)$ frente a las cuatro líneas de células tumorales ensayadas; sin embargo, la estrecha relación de su estructura con las de los bis(indolil)imidazoles topsentinas (Bartik et al., 1987), que son agentes antiinflamatorios de origen marino bien conocidos, nos lleva a proponer a los nuevos alcaloides de B. leachi como candidatos prometedores para ensayos antiinflamatorios (tabla 1).

A diferencia de las ascidias anteriormente reseñadas, el estudio químico de Stolonica socialis de la Isla de Tarifa dio lugar al aislamiento de una serie de metabolitos no nitrogenados, un resultado menos frecuente en la química de ascidias. Los ejemplares congelados de $S$. socialis se extrajeron con una mezcla 1:1 de acetona-metanol. Tras la evaporación del disolvente, el residuo acuoso se extrajo con éter etílico para rendir un extracto citotóxico activo frente al panel de líneas de células tumorales $\left(\mathrm{IC}_{50}=5 \mu \mathrm{g} / \mathrm{mL}\right)$. La separación guiada por bioensayos usando tanto cromatografía en columna como HPLC en fase reversa nos condujo a obtener tres pares 
active against the tumor cell lines panel $\left(\mathrm{IC}_{50}=5 \mu \mathrm{g} / \mathrm{mL}\right)$. Bioassay guided separation using both column chromatography and reversed phase HPLC led us to obtain three pairs of inseparable compounds: a mixture (9:1) of stolonoxide A [8] and stolonoxide B [9], a mixture (6:4) of their corresponding sodium salts [8a, 9a], and a mixture (6:4) of the sodium salts of stolonoxides $\mathrm{C}$ and $\mathrm{D}[\mathbf{1 0}, \mathbf{1 1}]$ (fig. 3).

The stolonoxides [8-11] are $\mathrm{C}_{24}$ acetogenins characterized for possessing a 1,2-dioxane ring connected to a tetrahydrofuran ring, whose structures differed either in the geometry of the side chain double bonds or in the stereochemistry of the five-membered ring. Since the above-mentioned mixtures proved to be inseparable under all HPLC conditions, a portion of the natural material was converted into the corresponding methyl esters 8b, 9b, 10a and 11a by treatment with diazomethane (Durán et al., 2000).

The plane structure of stolonoxide A [8] was established by means of the study of the high resolution mass spectrum and of the NMR data, in particular COSY and LRCOSY. The presence of a peroxide ring was confirmed by the characterization of the corresponding diol produced through dioxane ring opening upon palladium catalyzed hydrogenation of stolonoxide A [8].

The stereochemistry of each heterocyclic system was deduced by the correlations observed in the ROESY spectrum, while the spatial relation between both rings had to be inferred from the study of epoxide 12 (fig. 3) obtained by treatment of methyl ester $\mathbf{8 b}$ with aqueous $\mathrm{NaOH}$ followed by re-esterification with diazomethane. The epoxide thus obtained was found to possess a threo stereochemistry about C-6, C-7 and bore a single hydroxyl group, while retaining the absolute configuration at all stereogenic centers of the natural compound. This fact is quite remarkable since it allowed us to apply the Mosher method to epoxide $\mathbf{1 2}$ and thus unambiguously determine an absolute stereochemistry $3 S, 6 S, 7 S, 10 R$ for stolonoxide A [8]. A similar rationale allowed us to establish the structures of the remaining members of the stolonoxide family [9-11].

The cytotoxicity assays against the tumor cell lines showed that the stolonoxides $\mathrm{A}$ and $\mathrm{B}[\mathbf{8} / \mathbf{9}]$ are strongly cytotoxic against cell line P-388 $\left(\mathrm{IC}_{50}=0.01 \mu \mathrm{g} / \mathrm{mL}\right)$. The mixture of stolonoxides $\mathrm{C}$ and $\mathrm{D}$ [10/11] was also strongly active against cell lines P-388 and A-549 $\left(\mathrm{IC}_{50}=0.01 \mu \mathrm{g} / \mathrm{mL}\right)$. Interestingly, the synthetic derivatives $\mathbf{1 2}$ and the hydrogenation diol were inactive, demonstrating the importance of the 1,2-dioxane ring in relation to the antitumor activity (table 1).

Although the genus Pseudodistoma is renown as a prolific source of nitrogenous metabolites, in our expeditions to Tarifa Island we encountered specimens of $P$. obscurum, a species that had not been previously studied. Cytotoxicity guided isolation of a portion of the medium polar organic extract of lyophilized material led to the isolation of the new unsaturated amino alcohol obscuraminol A [13], which was the major component, together with an inseparable mixture of minor compounds [14-18]. These latter compounds could be isolated de compuestos inseparables: una mezcla (9:1) de stolonóxido A [8] y stolonóxido B [9], una mezcla (6:4) de sus correspondientes sales sódicas $[\mathbf{8 a}, \mathbf{9 a}$ y yna mezcla $(6: 4)$ de las sales sódicas de los stolonóxidos $\mathrm{C}$ and $\mathrm{D}[\mathbf{1 0}, \mathbf{1 1}]$ (fig. 3).

Los stolonóxidos [8-11] son acetogeninas $\mathrm{C}_{24}$ que se caracterizan por poseer un anillo de 1,2-dioxano conectado a otro de tetrahidrofurano, y cuyas estructuras diferían bien en la geometría de la cadena lateral o bien en la estereoquímica del anillo de cinco miembros. Puesto que las mezclas anteriormente mencionadas se revelaron inseparables bajo todas las condiciones de HPLC ensayadas, una parte del material natural se transformó en los correspondientes ésteres metílicos 8b, 9b, 10a y 11a por tratamiento con diazometano (Durán et al., 2000).

La estructura plana del stolonóxido A [8] se estableció mediante el estudio del espectro de masas de alta resolución y de los resultados de NMR, en concreto COSY y LRCOSY. La presencia de un anillo de peróxido se confirmó por la caracterización del correspondiente diol producido por apertura del anillo dioxánico mediante la hidrogenación catalizada por paladio del stolonóxido A [8].

La estereoquímica en torno a cada sistema heterocíclico se dedujo a partir de las correlaciones observadas en el espectro ROESY mientras que la relación espacial entre ambos anillos tuvo que establecerse a partir del estudio del epóxido $\mathbf{1 2}$ (fig. 3) que se obtuvo por tratamiento del metil éster $\mathbf{8 b}$ con $\mathrm{NaOH}$ acuoso y subsiguiente reesterificación con diazometano. Se demostró que el epóxido así obtenido poseía una estereoquímica treo en torno a C-6, C-7 y llevaba un único grupo hidroxilo, además de retener la configuración absoluta en todos los centros estereogénicos del compuesto natural. Este hecho es muy interesante puesto que nos permitió aplicar el método de Mosher al epóxido 12 y así, de forma inequívoca, determinar una estereoquímica absoluta $3 S, 6 S, 7 S, 10 R$ para el stolonóxido A [8]. Un razonamiento similar permitió establecer las estructuras de los restantes miembros de la familia de los stolonóxidos [9-11].

Los ensayos de citotoxicidad frente a las líneas de células tumorales pusieron de manifiesto que los stolonóxidos A y B [8/9] son fuertemente citotóxicos frente a la línea celular P-388 $\left(\mathrm{IC}_{50}=0.01 \mu \mathrm{g} / \mathrm{mL}\right)$. La mezcla de los stolonóxidos C y D [10/11] fue también fuertemente activa frente a las líneas celulares P-388 y A-549 $\left(\mathrm{IC}_{50}=0.01 \mu \mathrm{g} / \mathrm{mL}\right)$. Resulta interesante que los derivados sintéticos $\mathbf{1 2}$ y el diol de hidrogenación fueron inactivos, lo que demuestra la importancia del anillo de 1,2-dioxano en relación con la actividad antitumoral (tabla 1).

Aunque el género Pseudodistoma es reconocido como una prolífica fuente de metabolitos nitrogenados, en nuestras expediciones a la Isla de Tarifa encontramos ejemplares de $P$. obscurum, una especie que no había sido previamente estudiada. El aislamiento guiado por citotoxicidad de una parte del extracto orgánico de material liofilizado con polaridad media condujo al aislamiento del nuevo aminoalcohol 
only as their corresponding diacetyl derivatives [14a-18a], obtained after acetylation of the remaining natural extract (Garrido et al., 2001) (fig. 4).

The molecular constitution of the major component $\mathbf{1 3}$ was obtained by intepretation of high resolution mass spectrometry data and proton and carbon NMR spectra, and the presence of the characteristic 2-amino-3-hydroxypropyl unit was apparent. A careful interpretation of the correlations observed in the COSY spectrum allowed the location of the double bonds.

The stereochemistry was defined as follows. The relative stereochemistry of compound $\mathbf{1 3}$ was elucidated by interpretation of a series of NOEDS experiments in the oxazolidinone $\mathbf{1 9}$ (fig. 4) obtained by treatment of obscuraminol A [13] with 1',1'-carbonyldiimidazole. These experiments indicated a relative configuration erythro at C-2, C-3. Finally, the absolute configuration $R$ at $\mathrm{C}-3$, and therefore an absolute configuration $2 S, 3 R$, was deduced by application of the Mosher method on the $N$-acetylderivative of obscuraminol A [13]. A similar strategy led to the structural characterization of the remaining members of the obscuraminol series.

From a biogenetic point of view, the absolute configuration determined for the 2-amino-3-ol metabolites of P. obscurum requires $\mathrm{L}$-alanine and the corresponding fatty acids as biosynthetic precursors, in agreement with the biogenetic hypothesis proposed by Scheuer for the two epimeric 2-amino-3-ol derivatives isolated from an unidentified species of the genus Xestospongia and with which the obscuraminols share identical enantiomeric series (Gulavita and Scheuer, 1989).

Although the obscuraminols A-F [13-18] were active enough to be isolated using cytotoxicity guided fractionation, only obscuraminol A [13] could be tested in its natural form (table 1). In general the activities found can be considered mild since no significant $\mathrm{IC}_{50}$ values were found either for obscuraminol A [13] or the diacetyl derivatives [14a-18a].

In conclusion, the survey carried out by our research group on the antitumor properties of ascidians from the Gibraltar Strait shows the outstanding ability of these invertebrates to produce new compounds, some of them with promising pharmaceutical potential (Durán et al., 2001). Among the compounds which we have described, the stolonoxides [8-11] seem to be the most prominent cytotoxic agents. However, the testing of the obscuraminols [14-18] in their natural form rather than diacetyl derivatives together with the antitinflamatory testing of the alkaloids [5-7] from B. leachi, based on their structural similarities to the members of the topsentin family, are instances that should not be disregarded in the future.

\section{Acknowledgements}

This research was supported by grants from MCYT (research projects MAR98-0834 and PPQ2001-0020) and Junta de Andalucía (FQM-285). The biological material was collected and identified by S. Naranjo. Cytotoxicity assays were performed through a cooperation agreement with Instituto Biomar, S.A. insaturado obscuraminol A [13], que era el componente mayoritario, junto con una mezcla inseparable de compuestos minoritarios [14-18]. Estos últimos compuestos sólo pudieron ser aislados como los correspondientes derivados diacetilados [14a-18a] obtenidos tras acetilación del extracto natural restante (Garrido et al., 2001) (fig. 4).

La constitución molecular del componente mayoritario $\mathbf{1 3}$ se obtuvo por interpretación de los datos de espectrometría de masas de alta resolución y de los espectros de ${ }^{1} \mathrm{H}$ y ${ }^{13} \mathrm{C}$ NMR, de donde resultaba evidente la presencia de la característica unidad de 2-amino-3-hidroxipropilo. Una cuidadosa interpretación de las correlaciones observadas en el espectro COSY permitió la localización de los dobles enlaces.

La estereoquímica se definió como se explica a continuación: La estereoquímica relativa del compuesto $\mathbf{1 3}$ se elucidó por interpretación de una serie de experimentos NOEDS sobre la oxazolidinona 19 (fig. 4) obtenida por tratamiento del obscuraminol A [13] con 1',1'-carbonildiimidazol. Estos experimentos indicaban una configuración relativa eritro de los centros C-2, C-3. Finalmente, la configuración absoluta $R$ en el C-3 y, por consiguiente, una configuración absoluta $2 S$, $3 R$, se dedujo mediante la aplicación del método de Mosher al $N$-acetil derivado del obscuraminol A [13]. Una estrategia similar llevó a la caracterización estructural de los restantes miembros de la serie de los obscuraminoles.

Desde un punto de vista biogenético, la configuración absoluta determinada para los metabolitos 2-amino-3-oles de P. obscurum implica a la L-alanina y los correspondientes ácidos grasos como precursores biosintéticos, en concordancia con la hipótesis biogenética propuesta por Scheuer para los dos derivados 2-amino-3-oles epímeros aislados de una especie no identificada del género Xestospongia y con la que los obscuraminoles comparten una misma serie enantiomérica (Gulavita y Scheuer, 1989).

A pesar de que los obscuraminoles A-F [13-18] fueron lo suficientemente activos como para ser aislados mediante fraccionamiento basado en la citotoxicidad, sólo el obscuraminol A [13] se pudo probar en su estado natural (tabla 1). En general, las actividades encontradas resultaron ser bajas puesto que no dieron lugar a valores significativos de $\mathrm{IC}_{50}$ ni en el caso del obscuraminol A [13] ni en el de los derivados diacetilados [14a-18a].

Como conclusión, la revisión realizada por nuestro grupo de investigación acerca de las propiedades antitumorales de las ascidias procedentes del Estrecho de Gibraltar constata la asombrosa capacidad de estos invertebrados para producir nuevos compuestos, algunos con un potencial farmacológico prometedor (Durán et al., 2001). De entre los compuestos que hemos descrito, los stolonóxidos [8-11] parecen ser los agentes citotóxicos con una mayor proyección. Sin embargo, el ensayar los obscuraminoles [14-18] en su estado natural y no como diacetil derivados junto con las pruebas como antiinflamatorios de los alcaloides [5-7] de B. leachi, debido a su similitud estructural con los miembros de la familia de las topsentinas, son cuestiones a tener en cuenta de cara al futuro. 


\section{References}

Bartik, K., Braekman, J.C., Daloze, D., Stoller, C., Huysecom, J., Vandevyver, G. and Ottinger, P. (1987). Topsentins, new toxic bisindole alkaloids from the marine sponge Topsentia genitrix. Can. J. Chem., 65: 2118-2121.

Bergeron, R.J., Cavanaugh, P.F. Jr., Kline, S.J., Hughes, R.G. Jr., Elliot, G.T. and Porter, C.W. (1984). Antineoplastic and antiherpetic activity of spermidine catecholamide irons chelators. Biochem. Biophys. Res. Commun., 121(3): 848-854.

D'Incalci, M., Erba, E., Damia, G., Galliera, E., Carrassa, L., Marchini, S., Mantovani, R., Tognon, G., Fruscio, R., Jimeno, J. and Faircloth, G.T. (2002). Unique features of the mode of action of ET-743. Oncologist, 7: 210-216.

Durán, R., Zubía, E., Ortega, M.J., Naranjo, S. and Salvá, J. (1998). Phallusides, new glucosphingolipids from the ascidian Phallusia fumigata. Tetrahedron, 54: 14597-14602.

Durán, R., Zubía, E., Ortega, M.J., Naranjo, S. and Salvá, J. (1999). Novel alkaloids from the red ascidian Botryllus leachi. Tetrahedron, 55: 13225-13232.

Durán, R., Zubía, E., Ortega, M.J., Naranjo, S. and Salvá, J. (2000). Minor metabolites from the ascidian Stolonica socialis and cytotoxicity of stolonoxides. Tetrahedron, 56: 6031-6037.

Durán, R., Zubía, E., Ortega, M.J., Salvá, J., Fernández-Puentes, J.L., García-Grávalos, D. and Naranjo-Lozano, S. (2001). Stolonoxides. British Patent Application \#WO 01/83477 A1, November 8, 2001.

Fahy, E., Potts, B.C.M., Faulkner, D.J. and Smith, K. (1991). 6Bromotryptamine derivatives from the Gulf of California tunicate Didemnum candidum. J. Nat. Prod., 54: 564-569.

Faircloth, G.T., Stewart, D. and Clement, J.J. (1988). A simple screening procedure for the quantitative measurement of cytotoxicity assay. J. Tissue Culture Methods. 11(4): 201-205.

Faulkner, D.J. (2000). Marine pharmacology. Antonie van Leeuvenhoek, 77: 135-145.

Faulkner, D.J. (2002). Marine natural products. Nat. Prod. Rep., 19: $1-49$.

Fu, X., Ferreira, M.L.G., Schmitz, F.J. and Kelly-Borges, M. (1998). New diketopiperazines from the sponge Dysidea chlorea. J. Nat. Prod., 61: 1226-1231.

\section{Agradecimientos}

Esta investigación se sufragó mediante aportaciones del MCYT (proyectos MAR98-0834 y PPQ2001-0020) y de la Junta de Andalucía (FQM-285). El material biológico lo recolectó e identificó S. Naranjo. Los ensayos de citotoxicidad se realizaron en el marco de un convenio de colaboración con el Instituto Biomar, S.A.

Traducido al español por los autores.

Garrido, L., Zubía, E., Ortega, M.J., Naranjo, S. and Salvá, J. (2001). Obscuraminols, new unsaturated amino alcohols from the ascidian Pseudodistoma obscurum. Structure and absolute configuration. Tetrahedron, 57: 4579-4588.

Gulavita, N.K. and Scheuer, P.J. (1989). 2 Epimeric aminoalcohols from a sponge, Xestospongia sp. J. Org. Chem., 54: 366-369.

Jin, W., Rinehart, K.L. and Jares-Erijman, E.A. (1994). Ophidiacerebrosides: Cytotoxic glycosphigolipids containing a novel sphingosine from a sea star. J. Org. Chem., 59: 144-147.

Mosmann, T. (1983). Rapid colorimetric assay for cellular growth and survival: application to proliferation and cytotoxicity assays. J. Immunol. Methods, 65: 55-63.

Natori, T., Morita, M., Akimoto, K. and Koezuka, Y. (1994). Agelasphins, novel antitumor and immunostimulatory cerebrosides from the marine sponge Agelas mauritanus. Tetrahedron, 50: 2771-2784.

Rinehart, K.L. (1989). Novel anti-viral and cytotoxic agent. British Patent Application \# 8922026.3, September 29, 1989.

Rinehart, K.L., Holt, T.G., Fregean, N.L., Stroh, J.G., Kiefer, P.A., Sun, F., Li, L.H. and Martin, D.G. (1990). Ecteinascidins 729, 743, 745, 759B and 770: Potent antitumor agents from the Caribbean tunicate Ecteinascidia turbinata. J. Org. Chem., 55: 4512-4515.

Wright, A.E., Forleo, D.A., Gunawardana, G.P., Gunasekera, S.P., Koehn, F.E. and McConnell, O.J. (1990). Antitumor tetrahydroisoquinoline alkaloids from the colonial ascidian Ecteinascidia turbinata. J. Org. Chem., 55: 4508-4512. 